\title{
JUBILEUSZ PROFESORA JANUSZA JUSTYŃSKIEGO
}

W dniu 20 czerwca 2012 r. w Sali posiedzeń Rady Wydziału Collegium Iuridicum Novum Uniwersytetu Mikołaja Kopernika w Toruniu odbył się jubileusz siedemdziesięciolecia urodzin wybitnego historyka doktryn polityczno-prawnych prof. dra hab. Janusza Justyńskiego. Uroczystość połączona była z wręczeniem przygotowanej na cześć Dostojnego Jubilata ksieggi: Nam hoc natura aequum est... (red. A. Madeja, Wydawnictwo TNOiK, Toruń 2012, ss. 624), obejmującej biografię, opis działalności naukowej i kierunki badań, kompletną bibliografię prac Profesora z różnych dziedzin nauk prawnych.

Spotkanie zorganizowane zostało przez Wydział Prawa i Administracji toruńskiego Uniwersytetu. Władze uczelni reprezentowali Jego Magnificencja Rektor prof. dr hab. Andrzej Radzimiński i Prorektor ds. Kształcenia prof. dr hab. Danuta Janicka, zaś władze Wydziału - Dziekan prof. dr hab. Andrzej Sokala. Uroczystość stała się okazją do spotkania licznego grona przedstawicieli różnych dyscyplin prawa, szczególnie zaś znawców szeroko rozumianej myśli politycznej i prawnej. Wzięli w niej udział pracownicy Wydziału oraz goście przybyli z innych ośrodków akademickich w Polsce.

Uroczystość otworzył Dziekan Wydziału Prawa i Administracji UMK, prof. dr hab. Andrzej Sokala, który złożył Jubilatowi życzenia i gratulacje od całego toruńskiego prawniczego środowiska akademickiego. Wyraził także głęboką wdzięczność za wieloletnią pracę i zaangażowanie w kształcenie młodzieży, pracę naukową oraz pełnione w strukturze Uniwersytetu funkcje. Swe wystąpienie zakończył słowami Cycerona, w pełni oddającymi sylwetkę Jubilata: Vir clarissimus, Iuris prudens ilustrissimus, bonus et sapiens, bene meritus et dicendi peritus.

Następnie głos zabrała Prorektor prof. dr hab. Danuta Janicka, która przedstawiła życiorys naukowy Profesora. Janusz Justyński przyszedł na świat 13 VII 1941 roku w kolonii Czadziel, powiat prużański (obecnie Białoruś). Tragiczne wydarzenia wojny zadecydowały, iż po rozłące z ojcem, wraz z matką i młodszym bratem znalazł się na obszarze tzw. ziem odzyskanych. Po ukończeniu szkoły podstawowej rozpoczął naukę w I Liceum Ogólnokształcącym im. Juliusza Słowackiego w Elblągu. Pierwszy kontakt $\mathrm{z}$ Toruniem i uczelnią miał miejsce w 1959 roku, kiedy Janusz Justyński rozpoczął studia na Wydziale Prawa. Jego droga naukowa zarysowała się na czwartym roku studiów, gdy otrzymał stypendium naukowe w Katedrze Teorii Państwa i Prawa, której kierownikiem był prof. dr hab. Wiktor Kornatowski, wybitny specjalista historii antycznych doktryn polityczno-prawnych. Równolegle Janusz Justyński studiował filologię klasyczną na Wydziale Humanistycznym UMK. Praca dydaktyczna to najpierw ćwiczenia z teorii państwa i prawa oraz historii doktryn polityczno-prawnych, a od momentu uzyskania stopnia naukowego doktora także wykłady prowadzone w ośrodkach zamiejscowych w Bydgoszczy, Olsztynie i w Gdańsku. Już na tym etapie kształtowało się zainteresowanie dra Janusza Justyńskiego myślą fílozofíczną i społeczno-polityczną Indii. Wkrótce został prezesem toruńskiego oddziału Towarzystwa Przyjaźni Polsko-Indyjskiej. Jednak starania na terenie macierzystej uczelni długo napotykały przeszkody i długo rozbijały się o sprzeciw miarodajnych „czynników”: kandydat był uczniem działacza PAX-u i nie cieszył się zaufaniem władz. Roczny pobyt w Indiach miał miejsce dopiero w roku 1974, zaś jego owocem była rozprawa pt. Pań- 
stwo i prawo wideologii M.K. Gandhiego (Wydawnictwo Naukowe Uniwersytetu Mikołaja Kopernika, Toruń 1975), na podstawie której Janusz Justyński otrzymał stopień doktora habilitowanego. W 1978 roku dr hab. Janusz Justyński wyjechał po raz wtóry do Indii. Naukowym owocem tej wyprawy było wiele artykułów oraz praca pt. $M y s ́ l$ spoleczno-polityczna renesansu indyjskiego, od Rama Mohana Roya do Rabindranatha Agora (PWN, Warszawa-Poznań-Toruń 1985). Stała się ona następnie przesłanką do nadania Januszowi Justyńskiemu tytuhu profesora. W 1985 roku uzyskał stypendium Fundacji Kościuszkowskiej w Stanach Zjednoczonych i przez rok przebywal jako visiting professor na University of Wisconsin w Milwaukee. Zdobył nagrodę Kletschka Award. Okoliczności te określają kolejny kierunek zainteresowań badawczych Jubilata, co znalazło odzwierciedlenie w licznych publikacjach i tematyce organizowanych konferencji naukowych. Przełom lat osiemdziesiątych i dziewięćdziesiątych, który przyniósł Polsce wolność oraz perspektywę integracji europejskiej, przełożył się nie tylko na obszar badań naukowych Profesora, lecz przejawił także działania organizacyjne, a mianowicie powołanie Centrum Studiów Europejskich UMK, którego został kierownikiem, oraz Centrum Dokumentacji Europejskiej. Po akcesji Polski do Unii Europejskiej prof. Janusz Justyński skoncentrował się na pracy naukowej w Katedrze Historii Doktryn Polityczno-Prawnych, która w 2009 roku zorganizowała Ogólnopolski Zjazd Katedr Doktryn Polityczno-Prawnych.

Kolejnym mówcą był Jego Magnificencja Rektor UMK prof. dr hab. Andrzej Radzimiński. Wskazał on na znaczenie fundowania księgi jubileuszowej, stanowiącej wyraz wielkiego szacunku i uznania dla osiągnięć obdarowanej nią osoby.

Wręczenia księgi jubileuszowej dokonał redaktor tomu, mgr Andrzej Madeja. Określił on Księgę mianem symbolu wdzięczności za głębokie zaangażowanie i kilkadziesiąt lat oddanej pracy Profesora. Podkreślił, iż za Księgą płynie to, co najważniejsze, czyli gorące uczucia i pamięć. Wyraził żywione przez wszystkich pragnienie, by Profesor jak najdhużej troszczył się o losy toruńskiej Katedry Doktryn Polityczno-Prawnych.

Następnie prof. dr hab. Henryk Olszewski wygłosił przygotowaną na cześć Jubilata laudację. Przytoczmy in extenso pierwszy akapit wystąpienia:

„O Uczonym, któremu upływa siedemdziesiąty rok życia, a który - przeszedłszy wszystkie szczeble akademickiej drogi - doszedł na szczyt akademickiej hierarchii i może powołać się na poważne osiaggnięcia w badaniu, w nauczaniu i w działalności publicznej, mawia się w jubileuszowej konwencji, że życie poświęcił nauce. W odniesieniu do dokonań Profesora Janusza Justyńskiego uwaga ta wydaje się w pełni stosowna. Droga Jego była stroma i wyboista; sukces przychodził ciężko, ogromnym wysiłkiem i wyrzeczeniami. Zawdzięczał go szerokim zainteresowaniom i badawczej pasji, talentowi i pracowitości, solidnemu podkładowi kulturalnemu i uporowi w urzeczywistnianiu postawionych przed sobą zadań. Dochodził do nich skromnie i bez rozgłosu, wiedziony estymą dla nauki i poczuciem odpowiedzialności za rezultat badania. Ogłaszał wyniki swych dociekań nie po to, by zdobywać stopnie i tytuły; awansował, bo jego dorobek był zawsze wysokiej próby. Podobnie, nie dążył do zaszczytów i godności, jakie hojnie oferuje środowisko uniwersyteckie swoim luminarzom; wolał promować się - jak mó- 
wimy modnie - przez aktywność nieposzlakowaną etycznie, ważną poznawczo i społecznie użyteczną".

Mówca przedstawił czynniki, które określiły koleje życia Jubilata i ukształtowały Jego osobowość. W pierwszym rzędzie to bardzo trudne dzieciństwo, osobowość prof. Wiktora Kornatowskiego, ciekawość badawcza i wielostronność naukowych zainteresowań, poczucie społecznej służby.

W pierwszych latach siedemdziesiątych w bibliografii prac naukowych Janusza Justyńskiego zaczęły pojawiać się prace o tematyce indyjskiej. Młodemu badaczowi marzyło się pole dociekań nad doktrynami, których epicentrum stanowiły idee łączące problemy społeczno-polityczne i ustrojowe z możliwie solidną refleksją z zakresu etyki i filozofii praktycznej. Pierwszym owocem tych zainteresowań były mniejsze dzieła (wśród nich: Doktryna społeczno-polityczna Gandhiego-, Mahatmy,", ,Życie i Myśl” 1969, nr 1; Spoleczeństwo i państwo w ideologii „, indyjskiego renesansu”, „Czasopismo Prawno-Historyczne" 1973, XXIV, nr 2; Myśl ekonomiczna Gandhiego i jej rola w życiu wspólczesnych Indii, „Ruch Prawniczy, Ekonomiczny i Socjologiczny”, 1975, nr 3; Teoria narodu Gandhiego na tle imperialnej polityki Wielkiej Brytanii, „Acta Universitatis Nicolai Copernici. Nauki Polityczne", 1975, nr 7). Oczywiście dla sukcesu naukowego potrzebny był wyjazd do Indii, który doszedł do skutku dopiero w 1974 r. Autor powrócił do kraju po roku intensywnych studiów z gotową książką Państwo i prawo $w$ ideologii M.K. Gandhiego. Na jej podstawie habilitował się w 1975 r. na Wydziale Prawa i Administracji Uniwersytetu im. Adama Mickiewicza w Poznaniu. Książka miała charakter pionierski w piśmiennictwie polskim. Oparta na solidnej podstawie źródłowej i na dobrej wiedzy o stanie literatury przedmiotu, była jej weryfikacją i rozwinięciem. Ukazywała sylwetkę Gandhiego na szerokim tle porównawczym. Prezentowała go nie tylko jako teoretyka, ale także jako przywódcę wielkiego narodu, walczącego o niepodległość, jako polityka, który dysponował realnymi możliwościami kształtowania świadomości społeczeństwa indyjskiego.

Również książka Myśl społeczna i polityczna renesansu indyjskiego: od Rama Mohana Roya do Rabindranatha Tagora, wydana w 1985 roku, nie miała w literaturze polskiej poprzedników.

W kolejności głos zabrał prof. dr hab. Lech Dubel, kierownik Katedry Historii Doktryn Polityczno-Prawnych UMCS w Lublinie. Odczytał szereg adresów i listów gratulacyjnych skierowanych do Jubilata, przesłanych na ręce organizatorów m.in. przez przedstawicieli Katedr Doktryn Polityczno-Prawnych Uniwersytetu im. Adama Mickiewicza i Uniwersytetu Jagiellońskiego. Potem prof. Dubel przedstawił sylwetkę Jubilata jako członka społeczności historyków doktryn, w której cieszy się on wielkim szacunkiem.

Następnym z przemawiających była dr Marta Baranowska, która wystąpiła jako przedstawiciel uczniów i wychowanków Jubilata.

Na koniec głos zabrał sam Jubilat. Przywołując słowa znanego toruńskiego prawnika romanisty prof. dr. hab. Władysława Bojarskiego, zapewnił, iż przygotował na dzisiejszą uroczystość solenne wystąpienie, pragnął jednak zwrócić się do zgromadzonych w sposób bardziej bezpośredni i „mówić od serca". Jubilat odniósł się do wcześniejszych wystapień, w szczególności do wskazanych w laudacji kluczowych okolicz- 
ności, które zadecydowały o jego losie i zaskakujących związków, jakie dostrzega między nimi. Uzupełnił przytoczone koleje swego życia garścią osobistych przemyśleń $\mathrm{i}$ anegdot znanych do tej pory jedynie wąskiemu gronu. Wspominał początki współpracy z prof. Wiktorem Kornatowskim i pierwsze lata pracy na Wydziale Prawa. Szczegółowo opisał perypetie związane z ubieganiem się o zgodę na wyjazd do Indii, które przyćmiła wielka przygoda na subkontynencie. Przedstawił także początki swego zainteresowania problemem integracji europejskiej, które wykraczały dalece poza aspekty czysto naukowe. Wreszcie odniósł się do istoty uniwersytetu i społeczności akademickiej, do której należy i z którą łączy go bardzo silna więź. Dodał, iż korporacja uniwersytecka reprezentuje szczególną wartość, ale jednocześnie wymaga stałej troski o jej zachowanie. Kończąc, wyraził podziękowanie wszystkim organizatorom uroczystości jubileuszowej.

Część oficjalną uroczystości zamkną Dziekan prof. dr hab. Andrzej Sokala, czemu towarzyszyła tradycyjna lampka wina wzniesiona jako toast za zdrowie Jubilata.

ANDRZEJ MADEJA (Toruń)

\section{SYMPOZJUM HISTORYKÓW PAŃSTWA I PRAWA POLSKIEGO W KRAKOWIE (16 STYCZNIA 2012)}

Na Zjeździe Katedr Historyczno-Prawnych w Zegrzu w 2010 roku prof. Wacław Uruszczak przedstawił propozycję odbywania odrębnych konferencji historyków prawa polskiego. Taki był początek inicjatywy, która zaowocowała zorganizowaniem przez Katedry Historii Prawa Polskiego oraz Historii Administracji i Myśli Administracyjnej UJ w dniu 16 stycznia 2012 roku I Sympozjum Historyków Państwa i Prawa Polskiego w Krakowie. Organizatorzy Sympozjum początkowo planowali jego odbycie jesienią 2011 roku, a zatem w połowie dwulecia dzielącego Zjazdy Katedr Historyczno-Prawnych, jednak z powodu trudności technicznych (wiążących się z zaangażowaniem Uniwersytetu w trakcie polskiej prezydencji w Unii Europejskiej) spotkanie to zostało przeniesione na poczatek obecnego roku kalendarzowego. Idea, która przyświecała organizatorom, było umożliwienie prezentacji na wspólnej sesji plenarnej dłuższych wystapień (do 30 minut), dotyczących wybranych zagadnień. W związku z rocznicami, które przypadty w 2011 roku, jako tematy wiodące I Sympozjum Historyków Państwa i Prawa Polskiego zaproponowano dwa akty prawne epoki oświecenia, które w wieloraki sposób wpłynęły na rozwój prawodawstwa, orzecznictwa oraz świadomości prawnej mieszkańców ziem polskich: Konstytucję 3 maja oraz ABGB.

Do udziału w Sympozjum zgłosili się uczestnicy z Uniwersytetów: Warszawskiego, Śląskiego, Wrocławskiego, Łódzkiego, Rzeszowskiego, Marii Curie-Skłodowskiej w Lublinie, oraz Wyższej Szkoły Finansów i Zarządzania w Warszawie, a także przedstawicielka Uniwersytetu Wiedeńskiego reprezentująca zarazem Austriacką Akademię Nauk. Wśród wystąpień odnotować należy referat prof. Andrzeja Mączyń- 